\title{
Level of Social Capital of Beef Cattle Farmers who Carry Out Profit Sharing Systems with Universities
}

\author{
Sitti Nurani Sirajuddin ${ }^{1}$, Hastang ${ }^{2}$, Veronica Sri Lestari ${ }^{3}$, Rosmawaty $^{4}$ \\ \{ sitti.nurani@unhas.ac.id ${ }^{1}$, hastang_uh@yahoo.co.id ${ }^{2}$, veronicasrilestari@ unhas.ac.id ${ }^{3}$, \\ rosmawat_57@yahoo.co.id $\left.{ }^{4}\right\}$ \\ 1,2,3,4 Hasanuddin University, Indonesia
}

\begin{abstract}
This study aimed to determine the level of social capital of beef cattle farmers who follow the system for results with higher education (UNHAS). This research was conducted between May to June 2019 in Bangkala Sub-district, District of Maiwa, Enrekang Regency. Sample was choosed purposively totalled 27 person. The data were collected through observation and indepth interview by using a questionnaire. The research was descriptive quantitative. Analysis of the data used was frequency distribution using a Likert scale. The results of the study showed that the level of trust, linkage, reciprocity and norms was at a medium level.
\end{abstract}

Keywords: Social Capital, Beef Cattle Farmers, Sharing System, University.

\section{Introduction}

The significance of people is particular from the assets they have; as information becomes the "human capital" and social systems gotten to be the "social capital" [1]. Human capital is said to exist among people and it incorporates the instruction and work experience [2], though social capital is claimed to dwell within the connections [3].Social capital is one of the foremost cutting edge terms in ponders including economy, sociology and administration which have locked in the intellect of the scientists' ensuing common, financial, physical and human asset [4]. The precise character of social capital depends upon the express standards of behavior, the set of associations and the bunches that recognize the given setting, because it may be a multidimensional and socially particular notion [5] and works at the person, community and regulation levels [6]. It could be a sociological idea which alludes to the worth of social organizing, the participation and believe to accomplish specific benefits and is utilized as the organizing and social assets [7].

The measurements of social capital emphasize community fellowship to attain the objective of moving forward the quality of life, so that the require for advancement of values that must be adhered to by its individuals, such as: participatory demeanors, common consideration, giving and getting, and trusting each other. The measurements of social capital depict everything that creates society associated to realize a common objective on the premise of harmony, and in it is bound by values and standards that develop and are compiled [8]. 
The application of social capital to the partnership system is very important so that the system can be implemented. Partnerships are agreements between farmers / breeders and processors and / or marketing companies to produce and meet demand with agreed price agreements [9]]. Usually steady with the supposition of Strohm and Hoeffler [2006] [10] that associations are exceptionally prevalent in creating nations since it provides several points of interest. Moreover, the association framework in hamburger cattle commerce within the shape of a framework of comes about between beef cattle ranchers and Hasanuddin College has been carried out since 2015.

One of brushing regions overseen by Hasanuddin College is Maiwa Breeding Centre (MBC) in locale of Maiwa, Enrekang Regency. This 250 ha zone was built up as a center for the advancement of neighborhood cattle industry, particularly surveyed bovines, based on science and innovation. In expansion, contract-based organization frameworks have been started by Hasanuddin College with communities around the MBC, particularly in Bangkala Sub-district, Locale of Maiwa, and Enrekang Regency. With the usage of this framework, the $\mathrm{MBC}$ is anticipated to gotten to be the commerce unit of the encompassing animals rancher bunches and bolster the accessibility of hamburger cattle to realize self-sufficiency in meat generation in South Sulawesi Area and in Indonesia in common. In this manner, it is vital to know the application of social capital to the surrender framework between beef cattle farmers and Hasanuddin University

\section{Research Method}

This investigate was conducted between May to June 2019 in Bangkala Sub-district, Locale of Maiwa, Enrekang Rule. This investigate was quantitative clear. Populace who have as of now joined the organization framework with MBC. The subjects of this investigate were 27 ranchers. The information in this inquire about were gotten through perception and meet. The resultant information can be categorized as quantitative and subjective. The information were analyzed utilizing graphic measurements with recurrence conveyance and Likert Scale.

\section{Result and Discussion}

\subsection{Characteristic of Respondent}

Beef cattle farmer characteristics that may influence the livestock management are age, education level, the number of family members, business scale and the duration of farming [11]. The characteristics farmers who joined the profit sharing system with MBC is presented in Table 1

Table 1: Characteristics of farmers who had joined the profit sharing system with MBC in Maiwa sub-district, Enrekang Regency.

\begin{tabular}{lccc}
\hline Characteristic & $\begin{array}{l}\text { Number } \\
\text { (persons }\end{array}$ & $\begin{array}{c}\text { Percentag } \\
\text { e (\%) }\end{array}$ \\
\hline \multirow{2}{*}{ Age } & $0-14$ & 0 & 0.0 \\
\hline
\end{tabular}




\begin{tabular}{lccc} 
& 65 & 7 & 25.9 \\
& Senior High & 0 & 0 \\
School & & \\
Educationa & Junior High School & 10 & 37.0 \\
& Elementary School & 15 & 55.6 \\
Gender & None & 2 & 7.4 \\
& & 27 & 100 \\
Family members & Female & 0 & 0 \\
& $1-2$ & 2 & 7.4 \\
& $3-4$ & 15 & 55.6 \\
& $5-6 p^{\prime}$ & 10 & 37.0 \\
\hline
\end{tabular}

Source : primary data (2019)

The ages of beef cattle rancher who joined the benefit sharing framework were inside the profitable age (15-64 a long time) (Table 1. This shows that beef cattle ranchers ought to have the physical capacity to oversee the beef cattle commerce. The age of a agriculturist incorporates a noteworthy impact on the capacity to supply animals nourish from cultivate whose remove is generally distant absent from the animals cage. The foremost beneficial agriculturists as a rule have a energetic attitude and awesome physical capacities in overseeing their businesses. More youthful profitable age ranchers donate the ideal exertion to be more responsive toward changes. These farmers always want to try something new in an effort to improve their knowledge and business skill [12];[13].

\subsection{Perception oc Social Capital}

Social capital in a community rancher could be an item of human connections with one another, particularly hint connections and steady. Social capital alludes to the components though the parameters are trust, network and norms that have the potential efficiency of society, so that social capital is total and develop by itself [14]

This study analyzes the three main elements of social capital include: trust, networking and norms:

\section{Trust}

Trust is a form of willingness to take risks in social relations based on the conviction that somebody else will do something that's anticipated and to continuously act in a design of shared bolster activity [15]. Trust among individuals within the bunch and believe with the individuals of the bunch administration are surveyed in this think about as can be seen in Table 2 .

Table 2. Trust among Members in the sharing system

\begin{tabular}{|c|c|c|c|c|c|}
\hline$\overline{\mathrm{No}}$ & Category & Score & Frequency & Percentage & Weight \\
\hline 1 & High & 3 & 8 & 29.6 & 24 \\
\hline 2 & Middle & 2 & 19 & 70.4 & 38 \\
\hline 3 & Low & 1 & 0 & 0 & 1 \\
\hline
\end{tabular}

Source: Primary Data (2019) 
Table 2 appears that group's exercises interrelatedness of trust and certainty within the chairman of the individuals of the gather incorporate the category is center, it implies that the loyal individuals of a bunch of shared believe and give full certainty of the other individuals additionally the chairman of the gather. Shape of trust that happens in terms of making a difference, gather gatherings and bunch exercises. This is in accordance with the opinion of Fukuyama [2001] in Sheikh et al [2015] [8] that the trust (confidence) is a mutual trust in a society that allows these communities to unite with others and contribute to the improvement of social capital. Trust is a tool to build relationships that can reduce transaction costs, i.e. costs incurred in the process of exchange and the cost to make contact, contract and control [16]

\section{Networking}

Networking within the hypothesis of social capital implies the taking after:

a. There could be a bond between the hubs (the individual or bunch related with the media). Social relations were bound by shared believe both within the frame of methodology and within the shape of moralistic

b. Work between hubs (person or bunch) through the medium of social connections into one participation. Shortsighted respective certainty and believe in interpersonal are included in this category.

c. Just as with a net attached to each other intertwined work between the node and the weight together

The delineation of the organize of social capital within the gather of farmres who taken after the showroom program can be seen in Table 3

Table 3. Network on groups of farmers who joined the sharing system

\begin{tabular}{llllll}
\hline No & Category & Score & Frequency & Percentage & Weight \\
\hline 1 & High & 3 & 7 & 25.9 & 21 \\
2 & Middle & 2 & 16 & 59.3 & 30 \\
3 & Low & 1 & 4 & 14.8 & 4 \\
\hline
\end{tabular}

Source: Primary Data (2019)

Table 3 appears that the systems in bunches of farmers who connect the organization. framework is categorized as direct $(59.3 \%)$, which implies that farmers within the bunch for the most part making social systems and only one individual who does not build up a organize within the community. Social systems are shaped among the individuals within the bunch may be a organize of data and organizing for common offer assistance. The bunch individuals offer assistance each other and trade data and information to other individuals. Also, the head of the groups exchange information with members of the group, this is in accordance with the opinion of Praktikno [2008] that social systems are the result of person and community linkages. A solid social organize among the bunch individuals are completely fundamental in keeping up the cooperative energy and cohesiveness, and make a hint relationship between take after individuals of the gather conjointly with other parties.

3. Norm 
Norm in groups of farmers who take part within the showroom program features a part to smooth trade exercises and make great communities participate in the showroom program. has a role to smooth business activities and create good communities Kusumastuti [17] state that the norms as rules that have become habitual and institutionalized by mutual agreement. An understanding of the values and norms will create a community that is peaceful and calm so that the activity or business carried on running well. Norm on breeders can be seen in Table 4 .

Table 4. Norm at the farmers who take the program sharing system.

\begin{tabular}{|c|c|c|c|c|c|}
\hline No & Category & Score & Frequency & Percentage & Weight \\
\hline 1 & High & 3 & 10 & 37 & 30 \\
\hline 2 & Middle & 2 & 13 & 48.1 & 36 \\
\hline 3 & Low & 1 & 4 & 14.9 & 4 \\
\hline
\end{tabular}

Table 4 shows that members of the group of farmers who join the partnership system have a medium level of norms in compliance with the rules of the group. This means that farmers follow the jointly agreed rules and imposing sanctions. Behaviour of community members supervised and controlled by the applicable rulesthis is in accordance with the opinion of Cahyono and Adhiatma [18] that only common norms and values are generated by trust. Where this trust is hope towards orderliness, honesty, and cooperative behavior that arise from within a community that is based on the norms shared by its members.

\section{Conclusion}

Application social capital of farmers who participated in the sharing system ith university in the Maiwa District are at a middle level. Therefore, it is necessary to strengthen the network of groups which join the sharing system.

\section{Acknowledgment}

The authors thanks to the research and technology ministriesof Indonesia for facilitating this research. And the authors declare that there is no conflict of interest.

\section{References}

[1] V. Navarro, "Why" social capital"(like" disparities") is fashionable," Anthropologica, vol. 50, no. 2, pp. 423-425, 2008.

[2] B. H. Erickson, "Good networks and good jobs: The value of social capital to employers and employees," in Social capital, Routledge, 2017, pp. 127-158.

[3] M. Woolcock, "The place of social capital in understanding social and economic outcomes," Can. J. policy Res., vol. 2, no. 1, pp. 11-17, 2001.

[4] M. Mohsenzadeh, "Social capital influence on production.Interdisciplinary Journal of Contemporary Research in Business," pp. 497-510, 2011.

[5] M. J. De Silva, T. Harpham, S. R. Huttly, R. Bartolini, and M. E. Penny, "Understanding sources and types of social capital in Peru," Community Dev. J., vol. 42, no. 1, pp. 19-33, 2005.

[6] H. Shan, N. Muhajarine, K. Loptson, and B. Jeffery, "Building social capital as a 
pathway to success: community development practices of an early childhood intervention program in Canada," Health Promot. Int., vol. 29, no. 2, pp. 244-255, 2012.

[7] S. E. Seibert, M. L. Kraimer, and R. C. Liden, "A social capital theory of career success," Acad. Manag. J., vol. 44, no. 2, pp. 219-237, 2001.

[8] M. J. Sheikh, M. Redzuan, A. A. Samah, and N. Ahmad, "Identifying sources of social capital among the farmers of the rural Sindh province of Pakistan," Agric. Econ., vol. 61, no. 4, pp. 189-195, 2015.

[9] C. Eaton and A. Shepherd, "Contract farming: partnerships for growth (No. 145)," Food Agric. Org, 2001.

[10] K. Strohm and H. Hoeffler, "Contract farming in Kenya: Theory, evidence from selected Value Chains, and implications for development cooperation," PSDA Main Rep., 2006.

[11] B. Hartono and E. S. Rohaeni, "Contribution to income of traditional beef cattle farmer households in Tanah Laut Regency, South Kalimantan, Indonesia," Livest. Res. Rural Dev., vol. 26, no. 8, p. 10, 2014.

[12] J. A. Jermias, D. R. Tulle, C. L. O. Leo-Penu, and I. G. N. Jelantik, "Tingkat pendapatan peternak pada penggemukan sapi Bali dengan sistem bagi hasil di Kabupaten Kupang," Partner, vol. 17, no. 1, pp. 43-50, 2010.

[13] S. N. Sirajuddin and V. S. Lestari, "Livestock ecology research on institution and traditional sharing systems in cattle farms," EurAsian J. Biosci., vol. 13, no. 1, pp. 239-244, 2019.

[14] E. Suharto, "Islam, modal sosial dan pengentasan kemiskinan."," Bukan J, pp. 1-9, 2007.

[15] S. N. Sirajuddin, A. R. Siregar, and P. Mappigau, "Application of capital social of Bali cattle farmers that participate in the partnership system in Barru Regency, South Sulawesi Province," in IOP Conference Series: Earth and Environmental Science, 2018, vol. 157, no. 1, p. 12059.

[16] M. Heliawaty, S. A. Saleh, S. Darmawan, and R. Mappangaja, "Social capital and economic behavior of farmers," Int. J. Sci. Technol. Res., vol. 4, no. 1, pp. 89-91, 2015.

[17] A. Kusumastuti, "Modal sosial dan mekanisme adaptasi masyarakat pedesaan dalam pengelolaan dan pembangunan infrastruktur," Masy. J. Sosiol., pp. 81-97, 2015.

[18] B. Cahyono, "Peran modal sosial dalam peningkatan kesejahteraan masyarakat petani tembakau di Kabupaten Wonosobo," J. Ekon. Bisnis, vol. 15, no. 1, pp. 1-16, 2014.

Priyono dan Utami, 2012. Penguatan Modal Sosial dalam Upaya Meningkatkan Pendapatan Peternak sapi Potong di Kabupaten Banjarnegara. Surya agritama.1(1):1・10 